\title{
Pengembangan Bahan Ajar Daring Pada Materi Geometri SMP dengan Pendekatan Project Based Learning Berbantuan Software Wingeom
}

\author{
Risma Amelia ${ }^{1}$, Siti Chotimah ${ }^{2}$, Diana Putri ${ }^{3}$ \\ 1, 2, 3 IKIP Siliwangi, Jl. Terusan Jenderal Sudirman Cimahi \\ rismaamelia@ikipsiliwangi.ac.id
}

\begin{abstract}
This research to develop online teaching materials for geometry in junior high schools with a project-based learning approach assisted by Wingeom software that meets the criteria of being valid, practical and effective. This type of research is development research (R\&D), with 5 main stages, namely: (1) Preliminary study; (2) Design of teaching materials; (3) development (expert validation, testing, revision); (4) Implementation; (5) Evaluation. The subjects of this study were junior high school students in the city of Cimahi, with a sample of 35 students of class VII. The research was conducted in the even semester regarding the geometry material, namely quadrilateral. The aspect that is assessed from the development of these teaching materials is to produce teaching materials that are valid, practical, and effectively used in online learning. The validity of teaching materials is seen from the results of 5 validators who reach valid criteria with very good categories. The practicality of teaching materials reaches practical criteria in terms of teacher and student practicality sheets. and the effectiveness of teaching materials in terms of the achievement of student learning completeness. The results of field trials showed that $82 \%$ of students achieved KKM so that more than $80 \%$ of students were complete in learning triangles and rectangles, so that online teaching materials were geometry materials for junior high school with a project-based approach. Learning assisted by Wingeom software is effectively used. This research produces mathematics teaching materials in the form of lesson plans and online learning worksheets that are valid, practical and effective.
\end{abstract}

Keywords: Development, Teaching materials Online Learning, Geometry, Project Based Learning, Software Wingeom

\begin{abstract}
Abstrak
Penelitian ini bertujuan untuk mengembangkan bahan ajar daring materi geometri SMP dengan pendekatan project based learning berbantuan software wingeom yang memenuhi kriteria valid, praktis dan efektif. Jenis penelitian ini yaitu penelitian pengembangan (R\&D), dengan 5 tahapan utama yaitu: (1) Studi pendahuluan; (2) Desain bahan ajar; (3) pengembangan (validasi ahli, ujicoba, revisi); (4) Implementasi; (5) Evaluasi. Subjek dari penelitian ini yaitu siswa SMP di kota Cimahi, dengan sampel sebanyak 35 siswa kelas VII. Penelitian dilaksanakan pada semester genap mengenai materi geometri yaitu segiempat-segitiga. Aspek yang dinilai dari pengembangan bahan ajar tersebut yaitu menghasilkan bahan ajar yang valid, praktis, dan efektif digunakan pada pembelajaran daring. Kevalidan bahan ajar dilihat dari hasil 5 validator yang mencapai kriteria valid dengan kategori sangat baik, Kepraktisan bahan ajar mencapai kriteria praktis ditinjau dari lembar kepraktisan guru dan siswa. dan keefektifan bahan ajar ditinjau dari pencapaian ketuntasan belajar siswa. Hasil ujicoba lapangan diperoleh hasil $82 \%$ siswa mencapai nilai KKM sehingga lebih dari $80 \%$ siswa tuntas dalam mempelajari materi segiempat dan segitiga, sehingga bahan ajar daring materi geometri SMP dengan pendekatan project based learning berbantuan software wingeom efektif digunakan. Penelitian ini menghasilkan bahan ajar matematika berupa RPP dan LKS pembelajaran daring yang valid, praktis dan efektif.
\end{abstract}

Kata kunci: Pengembangan, Bahan Ajar Daring, Geometri, Project Based Learning, Software Wingeom

Copyright (c) 2021 Risma Amelia, Siti Chotimah, Diana Putri

$\triangle$ Corresponding author: Junitasari

Email Address: rismaamelia@ikipsiliwangi.ac.id (Jl. Terusan Jenderal Sudirman Cimahi)

Received 22 Desember 2020, Accepted 13 Februari 2021, Published 27 Maret 2021

\section{PENDAHULUAN}

Di Indonesia wabah virus corona masuk pada awal maret 2020 dengan penyebarannya yang sangat cepat, pada saat itu WHO menetapkan Covid-19 sebagai pandemi global. Sektor pendidikan merupakan salah satu yang terdampak akibat pandemi ini, proses belajar mengajar di sekolah dengan cara tatap 
muka harus dihentikan, semua digantikan dengan sistem daring dan belajar di rumah dengan menggunakan media-media online yang ada. Hal tersebut dilakukan sebagai usaha untuk mengurangi dan memutus penyebaran Covid-19. Berdasarkan hal itu, untuk pertama kali kementrian pendidikan Indonesia mengarahkan Work From Home atau bekerja dari rumah (Purwanto, 2020).

Berubahnya pola pembelajaran dari pembelajaran langsung menjadi pembelajaran online otomatis berdampak terhadap media dan bahan ajar yang digunakan guru dalam mengajar. Guru perlu berupaya menyiapkan bahan ajar yang efektif dan efisien untuk digunakan dalam pembelajaran daring. Namun berdasarkan hasil observasi dan pengamatan peneliti terhadap beberapa guru yang mengajar di Sekolah SMP maupun SMA di sekitar Kota Cimahi, kota Bandung, Kab. Bandung dan Kabupaten Bandung Barat masih banyaknya guru yang kesulitan dalam menyusun bahan ajar daring yang dapat digunakan pada pembelajaran daring. RPP yang digunakan masih menggunakan RPP lama dengan tidak mengacu pada kegiatan-kegiatan daring yang dilakukan, begitupun dengan LKS yang digunakan masih berisikan tugas-tugas dan soal yang perlu siswa kerjakan tanpa memperhatikan kebutuhan siswa dalam belajar mandiri. Siswa masih kesulitan untuk memahami materi dan masih memerlukan bimbingan guru sehingga siswa sulit belajar secara mandiri. Pembelajaran dominan dilakukan melalui Whatsapp grup dan pengiriman tugas melalui e-mail, sehingga masih banyak siswa yang kurang responsif dalam merespon pembelajaran di Whatsapp grup dan masih banyak siswa yang tidak mengirimkan tugasnya dikarenakan tidak memahami materi dan guru kurang mendalam menyampaikan materinya. Hal tersebut mendorong penulis untuk mengembangkan bahan ajar matematika untuk pembelajaran daring agar valid, praktis dan efektif digunakan pada pembelajaran daring.

Geometri merupakan pelajaran yang penting untuk dipelajari. Menurut Abdussakir (2009) karena banyak konsep yang termuat dalam matematika, geometri menempati posisi khusus pada kurikulum matematika. Geometri adalah penyajian secara abstrak dari pengalaman visual (penglihatan) dan spasial, misalnya bidang, pola, pengukuran dan pemetaan. Sedangkan dari sudut pandang matematika, geometri pada dasarnya menyediakan pendekatan-pendekatan untuk pemecahan masalah, misalnya gambargambar, diagram, sistem koordinat, vektor, dan transformasi. Peranan geometri dalam pelajaran matematika sangat penting, hal ini didukung oleh Depdiknas (Zuliana, 2013) yang menyebutkan bahwa materi pokok matematika penyumbang terbesar sekitar $40 \%$ dari seluruh materi pokok matematika di SMP/MTs yaitu Geometri. Geometri tidak hanya membina proses berpikir matematis siswa akan tetapi juga sangat mempengaruhi materi pelajaran lain dalam matematika. Jadi, geometri berperan hampir dalam setiap materi pada pelajaran matematika. Namun pelajaran geometri ini termasuk pelajaran matematika yang sulit dan kurang disenangi oleh siswa. Selain itu geometri juga bersifat abstrak sebagaimana pendapat Paradesa (2016) masih banyaknya siswa yang kesulitan dalam mempelajari bidang kajian geometri.

Materi bangun datar segiempat dan segitiga merupakan materi dasar geometri yang perlu dikuasai oleh siswa. Oleh karena itu, sangat penting bagi semua siswa untuk dapat menguasai materi tersebut. Akan tetapi penguasaan konsep segiempat dan segitiga masih tergolong rendah, serta masih banyak 
siswa yang mengalami kesulitan dalam menyelesaikan soal - soal yang terkait dengan konsep segiempat dan segitiga. Menurut Yuwono (2016), terdapat tiga kesulitan belajar peserta didik dalam mengerjakan soal materi segiempat dan segitiga yaitu kesulitan dalam memahami konsep, kesulitan dalam mengidentifikasi dan menyebutkan sifat - sifat, kesulitan dalam menentukan rumus yang meliputi kesulitan membuktikan jumlah besar sudut dalam suatu segitiga. Hal ini sejalan dengan penelitian Nursaadah, I., \& Amelia (2018) yang menyatakan bahwa pemahaman siswa pada materi segitiga dan segiempat masih tergolong rendah. Kesulitan siswa dalam mempelajari materi segiempat dan segitiga diantaranya siswa tidak dapat mengaitkan berbagai konsep (internal dan eksternal) matematika, dan belum mampu menerapkan konsep secara algoritmik. Amelia et al (2020) menyebutkan bahwa kurangnya pengetahuan siswa mengenai materi dapat terjadi karena ketidakpahaman siswa akan materi yang diajarkan dan kurangnya latihan dalam mengerjakan tugas atau project menyebabkan kemampuan kognitif, apektif, dan psikomotor siswa kurang terlatih. Selain itu terbatasnya bahan ajar yang digunakan dalam pembelajaran dapat pula menjadi penyebab kesulitan siswa dalam mempelajari materi yang diajarkan. Bahan ajar berperan dalam mengembangkan kemampuan intelektual, keterampilan, serta prestasi belajar siswa. Perlunya bahan ajar yang berkualitas dan sesuai dengan kebutuhan siswa sangat diperlukan dalam mempelajari materi segiempat dan segitiga terutama selama pembelajaran daring. Berdasarkan hal tersebut peneliti memilih materi geometri khususnya materi segiempat dan segitiga untuk mengembangkan bahan ajar daring pada penelitian ini.

Berdasarkan uraian diatas pentingnya menyusun bahan ajar yang berkualitas bagi guru selama masa pandemi ini, untuk mengefektifkan kegiatan pembelajaran daring yang dilakukan. Guru tentunya perlu optimal dalam menyampaikan materi dan melaksanakan pembelajaran meskipun dilakukan secara daring agar kompetensi pembelajaran dapat tercapai. Berkaitan dengan bahan ajar yang akan dikembangkan oleh peneliti, maka tidak terlepas dari tujuan pengembangan bahan ajar. Tujuan tersebut akan dapat dicapai berdasarkan pendekatan pembelajaran yang digunakan dalam bahan ajar. Pendekatan disesuaikan dengan kurikulum yang berlaku, peneliti menerapkan pendekatan Project Based Learning. Melihat karakteristik pendekatan Project based learning yang unik dan komprehensif, maka pendekatan ini cukup potensial untuk memperbaiki dan mengembangkan bahan ajar geometri SMP selama masa pandemi covid-19 ini.

Project Based Learning (PjBL) merupakan pendekatan pembelajaran yang memberikan kebebasan kepada peserta didik untuk merencanakan aktivitas belajar, melaksanakan proyek secara kolaboratif, dan pada akhirnya menghasilkan produk kerja yang dapat dipresentasikan kepada orang lain Purnomo, E. A., \& Mawarsari (2014). Tahapan PjBL adalah sebagai berikut : Pertama, Planning (perencanaan) pada tahapan ini kegiatan yang dilakukan adalah merancang seluruh proyek, mengorganisir pekerjaan, kegiatan dalam langkah ini adalah merencanakan proyek. Kedua Creating dalam tahapan ini siswa mengembangkan gagasan-gagasan proyek, mengkombinasikan ide yang muncul dalam kelompok, dan membangun proyek. Ketiga, Processing tahapan ini meliputi presentasi proyek dan evaluasi. Pada presentasi proyek akan terjadi komunikasi secara actual kreasi ataupun temuan dari investigasi 
kelompok, sedangkan pada tahapan evaluasi akan dilakukan refleksi terhadap proyek, analisis dan evaluasi dari proses-proses belajar. Berikut langkah-langkah pendekatan Project Based Learning pada penelitian ini:

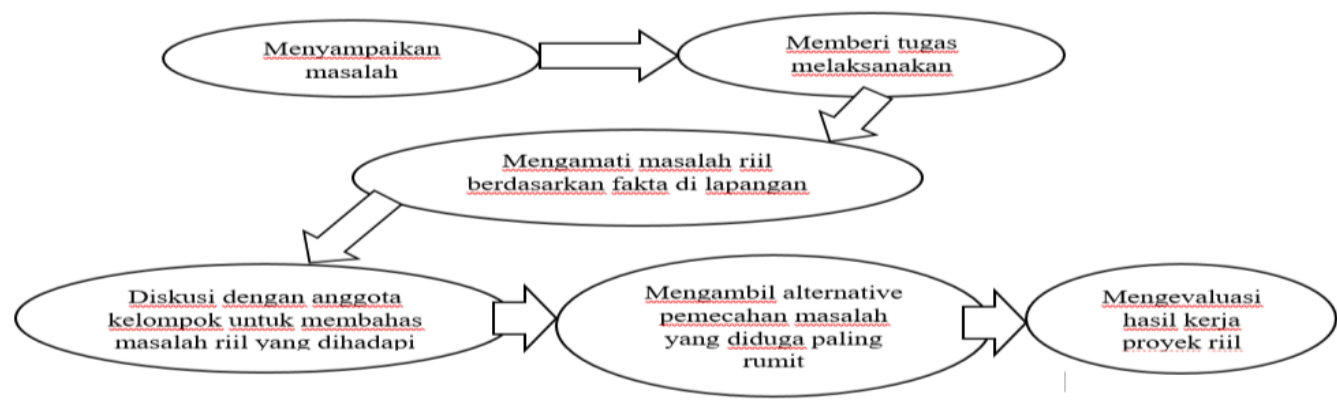

Gambar 1. Langkah-langkah Project Based Learning

Langkah-langkah pendekatan Project Based Learning yang akan dikembangkan dalam bahan ajar daring ini tentunya mengacu kepada kurikulum yang berlaku yaitu kurikulum 2013 pada masa pandemi (kurikulum darurat). Pendekatan Project Based Learning dengan berbatuan software wingeom untuk pemahaman konsep siswa pada materi segiempat dan segitiga menambah kualitas bahan ajar sehingga lebih inovatif, menarik dan materi yang diajarkan mudah dipahami oleh siswa. Menurut Astuti \& Wutsqa (2016) menyebutkan bahwa aktivitas belajar yang dilakukan siswa dengan pembelajaran project based learning dapat memberikan pengalaman nyata bagi siswa, selain itu siswa terfasilitasi untuk dapat berinvestigasi, memecahkan masalah, bersifat student centered dan menghasilkan produk berupa hasil proyek. Hal ini dapat membantu siswa belajar mandiri pada pembelajaran daring seperti saat ini.

Pembelajaran menggunakan software wingeom, dirasakan menjadi lebih menarik dan tidak monoton sehingga proses pembelajaran menjadi lebih menyenangkan. Rudhito (2008) menyatakan bahwa penerapan sotware wingeom lebih baik dibandingkan pembelajaran konvensional. Selain itu, pembelajaran menggunakan software wingeom juga lebih menyenangkan dan lebih menarik bagi siswa. Software Wingeom merupakan salah satu perangkat lunak komputer matematika dinamis untuk membantu pemecahan masalah geometri. Wingeom dibuat oleh Richard Parris. Program ini memuat wingeom 2-dim untuk geometri dimensi dua dan wingeom 3-dim untuk geometri dimensi tiga. Fasilitas program wingeom cukup lengkap, menarik, dan mudah digunakan. Gambar bangun-bangun geometri dimensi tiga dapat diputar sehingga visualisasi begitu tampak jelas. Pembelajaran dengan software wingeom dapat membantu peserta didik memvisualisasikan bentuk geometri dimensi dua maupun dimensi tiga yang abstrak menjadi lebih konkret sehingga peserta didik dapat lebih memahami konsep dan mencitrakannya dalam pikiran (Gusnidar, Netriwati, \& Putra, 2018 ).

Oleh karena itu, peneliti mengembangkan penelitian dengan judul pengembangan bahan ajar daring pada materi geometri SMP dengan pendekatan Project Based Learning berbantuan software wingeom. 


\section{METODE}

Jenis penelitian ini yaitu penelitian pengembangan (R\&D), dengan 5 tahapan utama yaitu: (1) Studi pendahuluan; (2) Desain bahan ajar; (3) pengembangan (validasi ahli, ujicoba, revisi); (4) Implementasi; (5) Evaluasi. Dengan alur penelitian sebagai berikut:

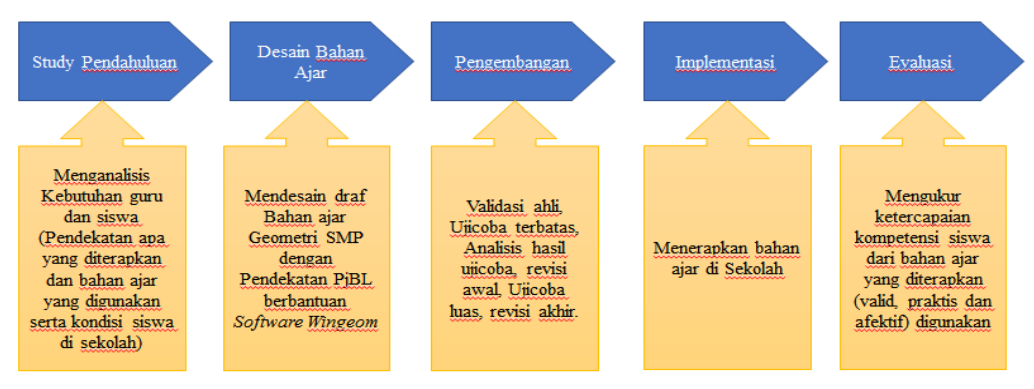

Gambar 2. Alur Penelitian

Produk yang dikembangkan berupa bahan ajar daring dengan pendekatan project based learning berbantuan software wingeom untuk pembelajaran daring, untuk memfasilitasi siswa SMP dalam mempelajari materi segiempat-segitiga. Subjek dari penelitian ini yaitu siswa SMP di kota Cimahi, dengan sampel sebanyak 35 siswa kelas VII di salah satu SMP Negeri di Kota Cimahi. Instrumen yang digunakan dalam penelitian ini yaitu:

\section{Lembar Validasi Ahli: Untuk Mengukur Kevalidan}

Penilaian kevalidan bahan ajar dilakukan oleh 5 validator yaitu diantaranya 2 dosen prodi pendidikan matematika dari IKIP Siliwangi yang terdiri atas 1 ahli pembelajaran dan 1 ahli media pembelajaran serta 3 guru mata pelajaran matematika SMP. Kriteria kevalidan sebagai berikut:

Tabel 1. Kriteria Kevalidan

\begin{tabular}{|c|c|c|}
\hline No & Interval Skor & Kriteria Penilaian \\
\hline 1 & $3,25<\mathrm{P} \leq 4,00$ & Sangat Valid \\
\hline 2 & $2,50<\mathrm{P} \leq 3,25$ & Valid \\
\hline 3 & $1,75<\mathrm{P} \leq 2,50$ & Kurang Valid \\
\hline 4 & $1,00 \leq \mathrm{P} \leq 1,75$ & Tidak Valid \\
\hline
\end{tabular}

Lembar observasi pelaksanaan bahan ajar yang diberikan terhadap guru, untuk mengukur kepraktisan dan keterpakaian bahan ajar. Subjek terdiri atas 35 responden siswa dan 4 responden guru. Berikut kriteria kepraktisan berdasarkan observasi terhadap siswa dan guru:

Tabel 2. Kriteria Kepraktisan berdasarkan Observasi terhadap Siswa

\begin{tabular}{|c|c|c|}
\hline No & Persentase (\%) & Kategori \\
\hline 1 & $0-20$ & Tidak Praktis \\
\hline 2 & $21-40$ & Kurang Praktis \\
\hline 3 & $41-60$ & Cukup praktis \\
\hline 4 & $61-80$ & Praktis \\
\hline 5 & $81-100$ & Sangat Praktis \\
\hline
\end{tabular}


Untuk mengukur kepraktisan bahan ajar berdasarkan observasi terhadap guru menggunakan skala Guttman sebagai berikut:

Tabel 3. Skala Guttman Berdasarkan observasi terhadap Guru

\begin{tabular}{|c|c|}
\hline Jawaban & Skor \\
\hline Ya & 1 \\
\hline Tidak & 0 \\
\hline
\end{tabular}

Perhitungan persentase data yang diperoleh dengan rumus sebagai berikut:

$$
\text { Kepraktisan }(\%)=\frac{\text { Jumlah skor tiap pernyataan }}{\text { Jumlah responden }} \times 100 \%
$$

Hasil belajar dan pencapaian kemampuan siswa: untuk mengukur keafektifan bahan ajar. Kriteria pencapaian ketuntasan siswa $\geq 80 \%$ diatas KKM maka pembelajaran tuntas dan bahan ajar efektif.

\section{HASIL DAN DISKUSI}

\section{Studi Pendahuluan}

Tahap awal yaitu studi pendahuluan peneliti menganalisis kondisi di lapangan dengan melaksanakan observasi terhadap Sekolah Menengah yang ada di sekitar Bandung Raya diantaranya Kota Cimahi, Kab. Bandung Barat, Kota Bandung, dan Kabupaten Bandung. Kurikulum yang digunakan di beberapa Sekolah yang peneliti jadikan subjek tempat studi pendahuluan masih beragam, ada yang masih menggunakan kurikulum 2013, kurikulum 2013 revisi, dan kurikulum darurat dimasa pandemi. Pembelajaran yang dilakukan masih dominan secara daring, meskipun ada beberapa sekolah yang sudah mulai melakukan tatap muka namun dalam waktu yang sangat terbatas hanya untuk mengumpulkan tugas atau guru memberikan tugas dalam bentuk modul. Modul yang digunakan didalam pembelajaran hanya sebatas tugas atau latihan tanpa adanya petunjuk dan bahan materi yang lengkap sehingga siswa kesulitan dalam memahami materi, dan sulit memahami perintah dari tugas yang disajikan. Dari hasil analisis awal menunjukkan bahwa kondisi pembelajaran daring di Sekolah SMP saat ini masih memerlukan perhatian. Pembelajaran masih belum efektif dilakukan, terdapat banyak kendala dalam pembelajaran diantaranya kesulitan guru dalam menyusun bahan ajar, dan media yang kurang mendukung, pembelajaran hanya sebatas tugas-tugas yang perlu siswa kerjakan tanpa pemaparan materi yang cukup bagi siswa, sehingga pemahaman siswa akan materi yang diajarkan masih tergolong rendah. Perlunya kreasi, inovasi dan kreatifitas guru dalam pembelajaran baik dalam menyusun bahan ajar maupun pendekatan yang diterapkan selama pembelajaran daring ini. Hal ini didukung oleh Octariani \& Rambe (2018) yang menyebutkan bahwa perlunya kreatifitas dalam penyampaian materi untuk mengarahkan minat dan kemauan peserta didik dalam belajar itu tergantung dari bahan ajar yang guru gunakan dan pendekatan yang guru terapkan dalam proses pembelajaran. Sedangkan pada pembelajaran online tentunya proses pembelajaran sangat berbeda dengan pembelajaran pada saat offline atau tatap muka langsung, keterbatasan waktu dan materi yang guru sampaikan menjadi kendala guru dalam proses pembelajaran. Hal ini sejalan dengan Amelia, at al (2020) 
yang menyebutkan bahwa pembelajaran online berbeda dengan pembelajaran offline, dimana guru tidak perlu menyampaikan semua materi pembelajaran sehingga semua kompetensi tidak harus tercapai. Akan tetapi guru fokus pada materi-materi yang essensial dan konsep dasar yang perlu disampaikan terhadap siswa. Oleh karena itu peneliti mengembangkan bahan ajar daring dengan pendekatan project based learning untuk meningkatkan pemahaman siswa pada saat pembelajaran online dengan tidak mengurangi essensi materi yang harus diajarkan, sehingga guru dapat tetap berinovasi dan siswapun dapat mengembangkan kemampuan dan kreatifitasnya dalam belajar.

Desain Bahan Ajar

Tahap selanjutnya yaitu desain bahan ajar, peneliti menyusun bahan ajar berupa RPP dan LKS untuk pembelajaran daring dengan memperhatikan struktur kurikulum yang berlaku yaitu kurikulum darurat berdasarkan kurikulum 2013 dimasa pandemi covid-19 dengan tahapan langkah-langkah pendekatan project based learning berbantuan software wingeom. LKS yang dikembangkan dalam penelitian ini berisi rangkuman materi segiempat dan segitiga yang dilengkapi dengan soal-soal dan petunjukpetunjuk kegiatan dan penyajian masalah kontekstual. Berdasarkan kendala guru dan siswa yang ditemukan dalam pembelajaran peneliti menyusun RPP dan LKS berdasarkan kebutuhan guru dan siswa dalam pembelajaran daring. Hal ini sejalan dengan pendapat Kadarisma, Fitriani, \& Amelia (2020) yang menyebutkan bahwa agar pembelajaran lebih efektif kita perlu mengetahui dan menelaah kendala dan kesulitan yang dihadapi oleh siswa dalam belajar sehingga dapat memberikan solusi yang tepat untuk perbaikan kualitas pembelajaran.

Bahan ajar disusun dengan menerapkan langkah kegiatan yang dapat mengkontruks siswa dalam memahami materi segiempat dan segitiga yang diajarkan. LKS ini disusun berdasarkan langkah-langkah pendekatan Project Based Learning dengan berbantuan Software wingeom untuk pemahaman siswa pada materi segiempat dan segitiga. Langkah pertama yang disajikan berupa penyampaian masalah yang berkaitan dengan materi segiempat dan segitiga. Langkah kedua yaitu pemberian tugas dengan petunjuk pengerjaan yang terstruktur dan sistematis berbantuan software wingeom sehingga siswa dapat memahami dan mengerti petunjuk yang disajikan. Langkah ketiga yaitu siswa mengamati masalah riil berdasarkan fakta yang siswa temukan di lapangan. Langkah keempat yaitu siswa berdiskusi dalam kelompoknya. Langkah kelima dari hasil diskusi kelompok siswa dapat menemukan alternatif pemecahan masalah lain. Selanjutnya evaluasi hasil kerja siswa. Bahan ajar tersebut membuat siswa dapat belajar secara mandiri, partisipatif, interaktif dan kolaboratif. Setiap akhir pembelajaran terdapat project yang harus siswa kerjakan dan project tersebut disajikan dengan petunjuk-petunjuk yang jelas dan dapat mengkonstruk pemahaman siswa mengenai materi segiempat dan segitiga.

Pengembangan, Implementasi dan Evaluasi

Selanjutnya yaitu tahap pengembangan yang terdiri dari validasi ahli, ujicoba dan revisi. Pada tahap ini peneliti melakukan uji kevalidan bahan ajar oleh ahli. Penilaian kevalidan bahan ajar yang dilakukan oleh 5 validator yaitu diantaranya 2 dosen prodi pendidikan matematika yaitu ahli pembelajaran dan ahli 
media pembelajaran serta 3 guru mata pelajaran matematika SMP, diperoleh hasil validasi bahan ajar sebagai berikut:

Tabel 4. Hasil Validasi Ahli

\begin{tabular}{|c|l|c|c|c|c|c|c|c|}
\hline No & Komponen & $\begin{array}{c}\text { Validator } \\
\mathbf{1}\end{array}$ & $\begin{array}{c}\text { Validator } \\
\mathbf{2}\end{array}$ & $\begin{array}{c}\text { Validator } \\
\mathbf{3}\end{array}$ & $\begin{array}{c}\text { Validator } \\
\mathbf{4}\end{array}$ & $\begin{array}{c}\text { Validator } \\
\mathbf{5}\end{array}$ & $\begin{array}{c}\text { Rata- } \\
\text { rata }\end{array}$ & Kriteria \\
\hline 1 & Konten (Isi) & 3.3 & 3.2 & 3.1 & 3 & 3.4 & 3.2 & Valid \\
\hline 2 & $\begin{array}{l}\text { Construct } \\
\text { (Struktur) }\end{array}$ & 3.4 & 3.2 & 3.14 & 3.2 & 3.3 & 3.25 & Valid \\
\hline 3 & Bahasa & 3 & 3.33 & 3.23 & 3.3 & 3.3 & 3.23 & Valid \\
\hline \multicolumn{2}{|c|}{ Rata-rata } & $\mathbf{3 . 2 3}$ & $\mathbf{3 . 2 4}$ & $\mathbf{3 . 1 6}$ & $\mathbf{3 . 1 7}$ & $\mathbf{3 . 3 3}$ & $\mathbf{3 . 2 3}$ & Valid \\
\hline \multicolumn{2}{|c|}{ Kriteria } & Valid & Valid & Valid & Valid & $\begin{array}{c}\text { Sangat } \\
\text { Valid }\end{array}$ & Valid & \\
\hline
\end{tabular}

Berdasarkan hasil analisis validasi ahli pada Tabel.4 diatas menunjukkan bahwa empat validator menyatakan bahan ajar tersebut valid dan satu validator menyatakan bahan ajar tersebut sangat valid, sehingga diperoleh rata-rata 3.23 hasil dari keseluruhan validasi ahli yang kesimpulannya menyatakan bahwa bahan ajar matematika pada materi segiempat dan segitiga dengan pendekatan project Based Learning berbatuan software wingeom tersebut valid untuk digunakan. Selain memberikan penilaian terhadap kevalidan bahan ajar validator juga memberikan masukan dan arahan terhadap perbaikan bahan ajar. Selain menganalisis hasil validasi bahan ajar, peneliti pun menganalisis uji kepraktisan bahan ajar melalui lembar observasi terhadap siswa dan guru. Berikut hasil uji kepraktisan bahan ajar menurut siswa:

Tabel 5. Hasil Uji Kepraktisan Siswa

\begin{tabular}{|c|c|c|}
\hline Responden & Persentase (\%) & Kategori \\
\hline 35 & 72 & Praktis \\
\hline
\end{tabular}

Hasil analisis uji kepraktisan bahan ajar berdasarkan jawaban siswa pada lembar observasi keterlaksanaan pembelajaran dan penggunaan bahan ajar diperoleh persentase sebesar $72 \%$ yang menunjukkan bahwa bahan ajar tersebut praktis digunakan oleh siswa dalam pembelajaran daring pada materi segitiga dan segiempat. Selain melihat hasil observasi terhadap siswa, uji kepraktisan pun dilihat dari analisis lembar observasi terhadap guru pada pelaksanaan pembelajaran. Berikut hasil uji kepraktisan bahan ajar menurut guru:

Tabel 6. Hasil Uji Kepraktisan Guru

\begin{tabular}{|c|c|c|}
\hline Responden & Persentase (\%) & Kategori \\
\hline 4 & 69 & Praktis \\
\hline
\end{tabular}

Berdasarkan hasil analisis uji kepraktisan menurut 4 orang responden guru mata pelajaran matematika di Sekolah Menengah Pertama bahan ajar matematika pada materi segitiga dan segiempat dengan pendekatan project Based Learning berbantuan software wingeom tersebut sebesar 69\% sehingga kesimpulannya bahan ajar tersebut praktis untuk digunakan pada saat pembelajaran daring. 
Selanjutnya untuk mengukur tingkat keefektifan bahan ajar dilihat dari hasil pencapaian belajar siswa berdasarkan Kriteria Ketuntasan Minimal (KKM) yang ditempuh siswa di kelas. Bahan ajar yang dikembangkan diujicobakan pada salah satu SMP dipilih satu kelas yang komprehensif dengan jumlah siswa sebanyak 35 siswa. Berikut hasil pencapaian belajar siswa dari penerapan bahan ajar yang digunakan:

Tabel 7. Hasil Pencapaian Belajar Siswa

\begin{tabular}{|c|c|c|}
\hline $\begin{array}{c}\text { Banyak } \\
\text { siswa }\end{array}$ & $\begin{array}{c}\text { Tuntas } \\
\text { (diatas KKM) }\end{array}$ & $\begin{array}{c}\text { tidak tuntas } \\
\text { (dibawah KKM) }\end{array}$ \\
\hline 35 & 29 & 6 \\
\hline Persentase & $\mathbf{8 2 \%}$ & $\mathbf{1 8 \%}$ \\
\hline
\end{tabular}

Berdasarkan Tabel.7 diatas hasil pencapaian siswa dalam belajar sebesar $82 \%$ siswa tuntas dan diatas KKM sehingga didapat kesimpulan bahwa bahan ajar pada materi segitiga dan segiempat dengan pendekatan project Based Learning berbantuan software wingeom tersebut efektif digunakan pada pembelajaran daring. Selain dilihat dari hasil pencapaian belajar siswa kemampuan afektif siswa pun meningkat, dilihat dari siswa lebih responsif dan antusias dalam mengikuti pembelajaran. Project yang tersaji pada bahan ajarpun melatih kemampuan psikomotor siswa dengan baik. Sehingga ketiga aspek kemampuan siswa baik kognitif, apektif, dan psikomotornya dapat meningkat pada siswa dengan diterapkannya bahan ajar daring pada materi segiempat dan segitiga dengan pendekatan project Based Learning berbantuan software wingeom ini.

Berdasarkan hasil deskripsi diatas penelitian ini menghasilkan bahan ajar daring pada materi segiempat dan segitiga dengan pendekatan project Based Learning berbantuan software wingeom yang valid, praktis, dan efektif digunakan pada saat pembelajaran daring. Namun disamping itu terdapat beberapa masukan dari validator ahli diantaranya yaitu soal yang disajikan dalam bahan ajar lebih sulit lagi tingkat kesukarannya agar critical thingking siswa lebih meningkat. Siswa dan guru perlu menguasai lebih dalam penggunaan software wingeom agar dapat mengeksplore penggunaan software wingeom ini untuk konsep-konsep matematika lain. Hal ini didukung Rhosyida (2015) kelebihan software wingeom dalam menyajikan bentuk-bentuk bangun geometri dalam dimensi dua maupun dimensi tiga secara dinamis mampu memfasilitasi siswa dalam pemahaman geometri secara lengkap dan real. Pemilihan pendekatan pembelajaran, media pembelajaran dan kualitas bahan ajar akan menentukan tercapainya kompetensi dasar yang diharapkan. Sehingga dengan bahan ajar daring pada materi segitiga dan segiempat dengan pendekatan project Based Learning berbatuan software wingeom membantu siswa dalam memahami materi yang diajarkan dan memudahkan siswa belajar secara mandiri. Siswa termotivasi dan semangat belajar dengan bantuan software wingeom yang digunakan. Hal ini sejalan dengan Dwiantoro, A., \& Kusumandari (2016) yang mengatakan bahwa pembelajaran project Based Learning merupakan pembelajaran yang inovatif yang menekankan pembelajaran kontekstual melalui kegiatan yang kompleks yang menjdikan siswa lebih memahami pembelajaran dengan segala aktivitas yang mendukung. Bahan ajar yang dihasilkan valid, praktis dan efektif 
digunakan dalam proses pembelajaran. Penelitian lebih lanjut untuk melihat dampak pembelajaran dengan pendekatan project based learning berbantuan software wingeom terhadap beberapa kemampuan matematis lainnya.

\section{KESIMPULAN}

Berdasarkan hasil pengembangan bahan ajar diperoleh hasil dari keseluruhan validasi ahli yang menyatakan bahwa bahan ajar daring matematika pada materi segitiga dan segiempat dengan pendekatan project Based Learning berbatuan software wingeom tersebut valid untuk digunakan dengan kategori sangat baik. Uji Kepraktisan berdasarkan analisis uji kepraktisan siswa dan guru bahan ajar daring matematika pada materi segitiga dan segiempat dengan pendekatan project Based Learning berbatuan software wingeom tersebut praktis untuk digunakan. Hasil pencapaian siswa dalam belajar belajar sebesar $82 \%$ siswa tuntas dan diatas KKM sehingga didapat kesimpulan bahwa bahan ajar pada materi segiempat dan segitiga dengan pendekatan project Based Learning berbantuan software wingeom tersebut efektif digunakan. Bagi siswa peneliti menyarankan untuk mengeksplor dan memanfaatkan bahan ajar seoptimal mungkin agar siswa dapat menambah wawasan, pengetahuan, kreatifitas, dan meningkatkan kemampuan matematika lainnya. Bagi guru peneliti menyarankan untuk dapat mengembangkan bahan ajar dengan pendekatan dan media yang lain agar pembelajaran lebih mudah dipahami oleh siswa, dan menarik antusias siswa dalam belajar.

\section{UCAPAN TERIMAKASIH}

Penulis mengucapkan terimakasih kepada Lembaga IKIP Siliwangi yang telah mendanai terbitnya jurnal ini melalui hibah penelitian internal dan terimakasih juga kepada tim jurnal Cendekia yang telah membantu mempubliskan artikel kami.

\section{DAFTAR PUSTAKA}

Abdussakir, A. (2009). Pembelajaran Geometri Sesuai Teori Van Hiele. Madrasah: Jurnal Pendidikan Dan Pembelajaran Dasar, 2(1).

Amelia, R., Kadarisma, G., Fitriani, N., \& Ahmadi, Y. (2020). The Effect of Online Mathematics Learning on Junior High School Mathematic Resilience During Covid-19 Pandemic. In Journal of Physics: Conference Series (Vol. 1657, No. 1, p. 012011). IOP Publishing.

Astuti, W. D., \& Wutsqa, D. U. (2016). Pengembangan bahan ajar dengan pendekatan project based learning pada materi program linear untuk siswa kelas X SMK. Jurnal Pendidikan Matematika$S 1,5(8)$.

Dwiantoro, A., \& Kusumandari, R. (2016). Meningkatkan Hasil Belajar Berbasis E-learning Elgg pada Model Project Based Learning. Indonesian Journal of Curriculum and Educational Technology Studies, 4((2)), 49-57.

Gusnidar, G., Netriwati, N., \& Putra, F. G. (2018). Implementasi strategi pembelajaran konflik kognitif 
Pengembangan Bahan Ajar Daring Pada Materi Geometri SMP dengan Pendekatan Project Based Learning Berbantuan Software Wingeom, Risma Amelia, Siti Chotimah, Diana Putri

berbantuan software wingeom dalam meningkatkan kemampuan pemecahan masalah matematis. Jurnal Edukasi Matematika Dan Sains, ., 5((2)), 62-69.

Kadarisma, G., Fitriani, N., \& Amelia, R. (2020). RELATIONSHIP BETWEEN MISCONCEPTION AND MATHEMATICAL ABSTRACTION OF GEOMETRY AT JUNIOR HIGH SCHOOL. ,. Infinity Journal, 9((2)), 213-222.

Nursaadah, I., \& Amelia, R. (2018). Analisis Kemampuan Pemahaman Matematis Siswa Smp Pada Materi Segitiga Dan Segiempat. Numeracy, 5((1)), 1-9.

Octariani, D., \& Rambe, I. H. (2018). Pengembangan bahan ajar berbasis project based learning berbantuan software geogebra. ,. MES:Journal of Mathematics Education and Science, 4((1)), 1621.

Paradesa, R. (2016). Pengembangan bahan ajar geometri transformasi berbasis visual. Jurnal Pendidikan Matematika RAFA, 2((1)), 56-84.

Purnomo, E. A., \& Mawarsari, V. D. (2014). Peningkatan kemampuan pemecahan masalah melalui model pembelajaran ideal problem solving berbasis project based learning. Jurnal Karya Pendidikan Matematika, 1((1)).

Purwanto, A. (2020). Studi eksplorasi dampak Work from Home (WFH) terhadap kinerja guru selama pandemi COVID-19. EduPsyCouns: Journal of Education, Psychology and Counseling, 2(1), 92 100.

Rhosyida, N. (2015). Pemanfaatan Program Wingeompada Pembelajaran Matematika untuk Meningkatkan Pemahaman Geometri Siswa. Trihayu, , . 1((3)), 259040.

Rudhito, M. A. (2008). Geometri dengan Wingeom. Yogyakarta: Universitas Sanata Dharma.

Yuwono, M. R. (2016). Analisis kesulitan belajar siswa kelas VII SMP dalam menyelesaikan soal materi segitiga dan alternatif pemecahannya. Magistra, 28((95)), 14.

Zuliana, E. (2013). Meningkatkan Kemampuan Komunikasi Matematika Peserta Didik Kelas VIII B MTS N Kudus Melalui Model Cooperative Learning Tipe Jigsaw Berbantuan Kartu Masalah materi Kubus dan Balok. 